\title{
シラカンバ花粉症患者における咽喉頭症状と喉頭アレルギー
}

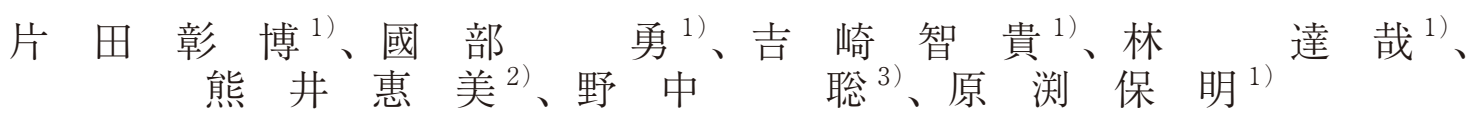

\section{Pharyngolaryngeal Symptoms and Laryngeal Allergy in Patients with Birch Pollen Nasal Allergy}

\section{Akihiro Katada ${ }^{1)}$, Isamu Kunibe ${ }^{1)}$, Tomoki Yoshizaki $^{1)}$, Tatsuya Hayashi ${ }^{1)}$ Megumi Kumai $^{2)}$, Satoshi Nonaka ${ }^{3)}$ and Yasuaki Harabuchi ${ }^{1)}$}

The clinical symptoms of laryngeal allergy are persistent cough, itching and irritation of throat. A clinical study focused on the diagnosis of laryngeal allergy was carried on 159 patients with nasal allergic symptoms from birch pollen (birch pollinosis). The diagnosis of birch pollinosis was confirmed by the clinical symptoms of seasonal rhinitis along with the presence of the specific anti-birch IgE antibody by CAP-RAST testing. Laryngeal allergy was diagnosed according to the criteria proposed by the Society of Study for Laryngeal Allergy in Japan (2005). Eighty-eight out of 159 (55.3\%) birch pollinosis patients were diagnosed as having laryngeal allergy. Laryngeal allergy patients suffer from seasonal pharyngolaryngeal symptoms, such as persistent coughing (40.2\%) and foreign-body sensation in the larynx (100\%). It is well known that patients with birch pollinosis frequently have oral symptoms after fruit and vegetable ingestion, which has been termed oral allergy syndrome (OAS). Forty-eight out of 88 (54.5\%) birch pollinosis patients with laryngeal allergy and 40 out of 71 (56.4\%) patients without laryngeal allergy were diagnosed as OAS. It is considered that the new criteria would be effective for the diagnosis of laryngeal allergy for patients with birch pollinosis.

Key words : birch pollinosis, laryngeal allergy, diagnostic criteria, pharyngolaryngeal symptoms, oral allergy syndrome

\section{は じめに}

鼻アレルギー患者が鼻症状とは別に慢性的な咽喉頭異常 感や咳嗽を訴えることは日常診療でもよく経験される。こ のような病態に対して,「喉頭アレルギー」という疾患概 念が提唱されている。喉頭アレルギーに関する報告は 1970 年頃から散見されるが ${ }^{1 \sim 3)}$ ，本邦では広く認知され るには至らなかった。本邦では 1988 年に喉頭アレルギー 研究会が組織され，1995 年には喉頭アレルギー研究会世 話人会から喉頭アレルギーの診断基準が示された。しか し, この診断基準では類似疾患との鑑別が難しく, さらに 喉頭アレルギーについても季節性のものと通年性のものに わけて対応することが妥当であることから, 現在も多施設 共同研究班を中心に診断基準の見直しが検討されている.

喉頭アレルギーの症状は持続する執拗な咳嗽と咽喉頭異 常感である．本邦の代表的な樹木花粉症であるスギ花粉症 患者が慢性咳嗽や咽喉頭異常感を訴えることは以前から指 摘されていた ${ }^{4)}$ 。このため, 季節性喉頭アレルギーの咽喉
頭症状については，スギ花粉症患者を対象にした検討が数 多くなされている ${ }^{5 \sim 8)}$ ，しかし，北海道に执いてはその植 生の違からスギ花粉症の報告はほとんど認められず，かわ りにシラカンバ花粉症が代表的な樹木花粉症となってい る。 シラカンバはカバノキ属の樹木であり，本州では岐阜 県以東で標高が $1500 \mathrm{~m}$ 以上の山岳地帯に分布している. 北海道内では丘陵地や山岳地帯だけではなく, 低地帯にも 広く分布することから, 市街地でもよくみかけられる樹木 であり，4 月下旬から 6 月上旬にかけて, 大きく垂れ下がっ た雄花から 3 孔型の花粉が飛散する ${ }^{9)}$ (図 1)。シラカンバ 花粉症患者の咽喉頭症状としては, 口腔アレルギー症候群 (Oral Allergy Syndrome, 以下 OAS) の関与がよく知られ ている ${ }^{10,11)}$. OASは原因となる特定の食物を摂取した直 後に口腔粘膜の腫脹やかゆみを引き起こし，ときに喉頭浮 腫などの重篤な状態や全身症状を誘発する即時型アレル ギー反応の総称である ${ }^{12)}$ ．以前に我々は，1995 年の喉頭 アレルギー診断基準を用いると, OASを合併しているシ ラカンバ花粉症患者では $72 \%$ が喉頭アレルギー確実例と

1) 旭川医科大学耳鼻咽喉科・頭頸部外科

2)くまいクリニック

3）のなか耳鼻咽喉科・気管食道科

1) Department of Otolaryngology-Head and Neck Surgery, Asahikawa Medical University

2) Kumai Clinic

3) Nonaka ENT Clinic 
なり，さらに疑い例までを含めると $90 \%$ の患者が喉頭ア レルギーと診断されることを報告した ${ }^{13)}$ 。この結果は, 1995 年の診断基準が OAS と喉頭アレルギーとの鑑別には 不向きであることを示唆していた。 その後, 喉頭アレル ギーの診断基準については 2000 年と 2005 年に 2 度の見 直しがおこなわれている。しかし，新しい診断基準案に基 づたシラカンバ花粉症患者における喉頭アレルギーの合 併率や, 咽喉頭症状に関する詳細な検討はなされていな い.

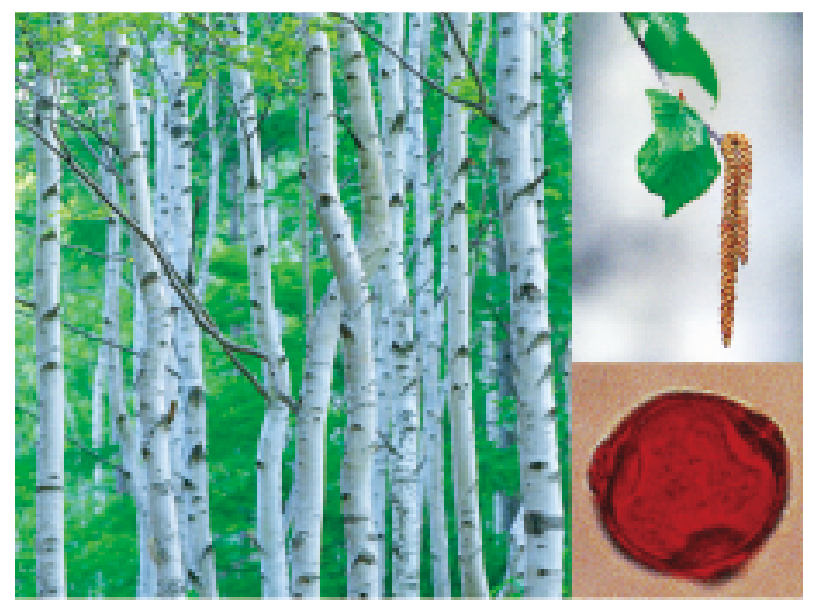

図 1 シラカンバの樹木, 雄花 (右上), 花粉 (右下) の写真
本研究では，シラカンバ花粉症患者を対象として咽喉頭 症状に関するアンケート調査をおこない, シラカンバ花粉 症における喉頭アレルギーの合併やOASとの関連性につ いて検討した。

\section{対 象と方 法}

対象は, 2002 年から 2009 年までの間に旭川医科大学耳 鼻咽喉科・頭頸部外科および当科関連施設に通院したシラ カンバ花粉症患者 181 名とした. シラカンバ花粉症の診断 は, 典型的な鼻アレルギーの症状 (くしゃみ, 水性鼻漏, 鼻閉）が季節性に存在し，鼻汁好酸球およびCAP-RAST 検査 (FEIA法) が陽性である症例とした. CAP-RASTで はRASTスコアが2 $(0.70 \mathrm{UA} / \mathrm{ml})$ 以上を陽性とした。

対象患者の咽喉頭症状を検討するために問診票 (表 1 ) によるアンケート調査をおこなった。問診票は合併して いるアレルギー疾患, 家族歴に加えて鼻症状, 咳嗽, の どの異常感について発症時期, 持続期間, 程度, 性状, 治療内容やその効果について詳細に記入できるようにし た。 その他, 胃酸逆流症状, 喘鳴, 呼吸困難, 嚥下困難, 嗄声の有無に関する質問項目も設けた.

喉頭アレルギーの診断は, アンケート結果と診療録を 参考に喉頭アレルギー多施設共同研究班の季節性喉頭ア レルギーのきびしい診断基準案 $(2005 \text { 年案 })^{14)}$ に基づいて おこなった (表 2$)$ 。このきびしい診断基準案では, 季節

表 1 検討にもちいた問診表

質問 1 、今までに次の病気にかかったことがありますか。あるものに○をつけて下さい。 気管支喘息、アレルギー性鼻炎（花粉症を含む）、アレルギー性結膜炎、アトピー性皮膚炎、じんましん、 副鼻腔炎（ちくのう）、逆流性食道炎、高血圧、気管支炎、 食物のアレルギー（具体的に： 薬のアレルギー（具体的に： その他（

質問 2 . 現在、何かお薬を飲んでいれば記入して下さい（薬品名もわかれば詳しく）

質問 3 ．血縁の方で次の病気にかかったことがありますか。あるものに○をつけて下さい 気管支喘息、アレルギー性鼻炎（花粉症を含む）、アレルギー性結膜炎、アトピー性皮膚炎、じんましん、 食物のアレルギー（具体的に： 薬のアレルギー（具体的に： その他（

質問 4.鼻の症状（くしゃみ、鼻水、鼻づまり）はありますか。 ある(今はないがよくある場合も含む)、ない

「ない」と答えた方は、質問 5 一。の他の方は、以下の質問にお答え下さい。

1）鼻の症状の出やすい時期を下からすべて選んで○をつけて下さい。

1 月、 2 月、 3 月、 4 月、 5 月、 6 月、 7 月、 8 月、 9 月、 10 月、 11 月、 12 月

一年中、特に決まっていない

2）1日の鼻をかむ回数は何回ぐらいですか。（時間をおいてでる回数）

21 回以上、 $11 \sim 20$ 回、 $6 \sim 10$ 回、 5 回以下、ない

3）どのような鼻汁がでますか。

さらさらしている、粘り気がある、透明、黄色、緑色

4） 1 日のくしゃみの発作の回数は、何回ぐらいですか（時間をおいてでる回数）。 21 回以上、 $11 \sim 20$ 回、 $6 \sim 10$ 回、 5 回以下、ない

5）鼻づまりの程度について次から 1 つ選んで下さい。

口呼吸が 1 日中続いている（鼻では息ができないほど鼻閉がひどい）

鼻閉が非常に強く、、呼吸が 1 日のうちでかなりの時間ある

鼻閉が強く、口呼吸が 1 日のうち時々ある

口呼吸はまったくないが鼻閉あり

鼻づまりはない 
質問 5 . 鼻水がのどにたれてくる感じはありますか。 ある（今はないがよくある場合も含む）、ない

「ない」と答えた方は、質問 6 へ。それ以外の方は、以下の質問にお答え下さい。

1）鼻水がのどにたれてくる感じがする時期を下からすべて選んで○をつけて下さい 1 月、 2 月、 3 月、 4 月、 5 月、 6 月、 7 月、 8 月、 9 月、 10 月、 11 月、 12 月 一年中、特に決まっていない

2）鼻水がのどにたれてくる感じは、花粉症の症状と一致しておこりますか。 はい、いいえ

質問 6 ，咳はでますか。 ある（今はないがよくある場合も含む）、ない

「ない」と答えた方は、質問 7 へ。それ以外の方は以下の質問にお答え下さい。

1）咳の種類は次のどちらですか。下から選んで下さい。 乾いた咳（から咳）、湿った咳（痰のからんだような咳）

2）咳はどれくらいの期間続きますか。 約—(年、ヶ月、週、日) 続く。

3）咳が出やすい時期を下からすべて選んで○をつけて下さい。 1 月、 2 月、 3 月、 4 月、 5 月、 6 月、 7 月、 8 月、 9 月、 10 月、 11 月、 12 月 一年中、特に決まっていない

4）咳は花粉症の症状と一致しておこりますか。はい、いいえ 「はい」の場合何年前からですか？（）年前から

5）一日の咳発作の回数は平均して何回ですか。次から選んで下さい。 21 回以上、 $11 \sim 20$ 回、 $6 \sim 10$ 回、5 回以下

6）今までの咳に対する治療を受けたことがありますか。

ある、 ない

治療を受けたことがある場合、その内容および効果を記入してください。

治療内容 :

治療効果 : 良くなった

良くなったが、決まった季節に再発する、 そのまま直らずに続いている

質問 7.のどの異常感（のどがなんか変な感じ、いがいがする感じ、など）がありますか。 ある（今はないがよくある場合も含む）、ない

「ない」と答えた方は、質問 8 ○それ以外の方は以下の質問にお答え下さい。

1）のどの異常感はどれくらいの期間続きますか。 約 —(年、ケ月、週、日) 続く。

2）のどの異常感が出やすい時期を下からすべて選んで○をつけて下さい。

1 月、 2 月、 3 月、 4 月、 5 月、 6 月、 7 月、 8 月、 9 月、 10 月、 11 月、 12 月

一年中、特に決まっていない

3）のどの異常感は花粉症の症状と一致しておこりますか。はい、いいえ

「はい」の場合何年前からですか? ）年前から

4）今までののどの異常感に対する治療を受けたことがありますか。 ある、 治療を受けたことがある場合、その内容および効果を記入してください。 治療内容 :

治療効果 : 良くなった

良くなったが、決まった季節に再発する、

そのまま直らずに続いている

5）のどの異常感の種類を、次の中から選んで下さい（いくつ選んでもかまいません）。 なんか変な感じ、いがいがする感じ、かゆい感じ、たんがからむ感じ、何かはりついている感じ 何かつかえている感じ、乾燥した（かわいた）感じ、のみこみにくい感じ、のどがしめつけられる感じ、 鼻水がのどにたれてくる感じ、息がつまってしまいそうな感じ（呼吸がしにくい感じ）、 その他（

質問 8．次の症状があれば○をつけて下さい。 胸やけ、げっぷ、むかつき、胃液（胃酸）の逆流、胃の痛み、胃の不快感、 これらの症状は、のどの異常感や咳に影響しますか。影響する、しない

質問 9. 咳やのどの異常感と同じ時期にのどの痛みはありますか。 ある、ない

質問 10 ．咳やのどの異常感と同じ時期に声がれはありますか。ある、 ない

質問 1 1. 咳やのどの異常感と同じ時期に呼吸するときにヒューヒュー、ゼイゼイ音が することがありますか。 ある、ない

質問 12 . 咳やのどの異常感と同じ時期に呼吸困難感（呼吸ができない感じ、息が つまってしまう感じ) はありますか。 
表 2 季節性喉頭アレルギーのきびしい診断基準案 (2005 年案)

季節性喉頭アレルギーのきびしい診断基準案（2005年案）

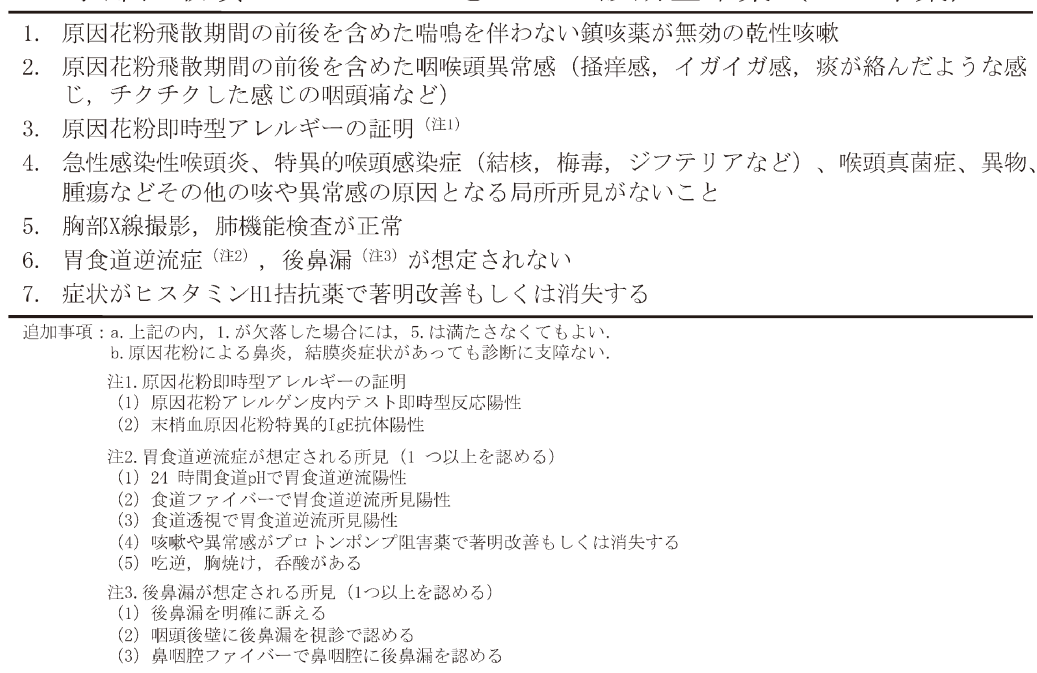

性喉頭アレルギーには胃食道逆流症, 後鼻漏が想定され ないことが明記されている。胃食道逆流症によると思わ れる症状やプロトンポンプ阻害薬による症状の改善が認 められた症例，後鼻漏を明確に訴える症例，視診で後鼻 漏がみとめられた症例は，季節性喉頭アレルギーから除 外した. OASの診断は特定の食物を摂取後におこる口腔・ 咽喉頭の掻痒感や腫脹の有無について問診をおこない, 原因となる食物が明らかな場合にはそれを記載しても らった。統計学的検討については $\chi^{2}$ 検定を用いた。

\section{結果}

対象のうちアンケートの回答が得られた 159 例のシラ カンバ花粉症患者について, 季節性喉頭アレルギーのき びしい診断基準案に基づいて診断をおこなった。 159 例 中, 咳嗽や咽喉頭異常感が認められない症例が 16 例, 喘 鳴が認められた症例が 31 例，後鼻漏が認められた症例が 8 例, 胃食道逆流症が認められた症例が 25 例であり，合 計で 71 症例が除外された。診断基準案をみたし季節性喉 頭アレルギーと診断された症例は 159 例中 88 例 (55.3\%) であった（図 2)。性差と年歯分布については, 回答が得 られた症例全体の男女比が $1: 2$ であり, 喉頭アレルギー 症例についても同様の男女比を示していた. 年齢のピー クについても症例全体と喉頭アレルギー症例の間に違い を認めなかった（図2).

喉頭アレルギーの 2 大症状は咽喉頭異常感と執拗な咳 嗽である。今回の検討の結果, 咽喉頭異常感については 143 例 $(89.9 \%)$ に認められ, 咳嗽と咽喉頭異常感の両方 を訴えた症例は 80 例 $(50.3 \%)$ であった。咳嗽のみを訴 えた症例は認められなかった。喉頭アレルギーの症例に はその診断基準からもわかるように全例で咳嗽もしくは
咽喉頭異常感が認められたが，喉頭アレルギーなしと診断 された症例においても 71 例中 55 例 $(77.5 \%)$ に咳嗽もし くは咽喉頭異常感が認められていた（図 3 ).

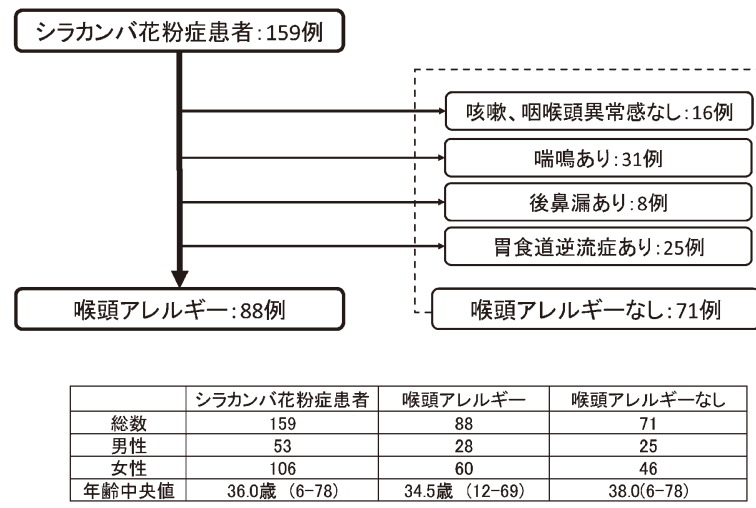

図 2 喉頭アレルギー患者のまとめ

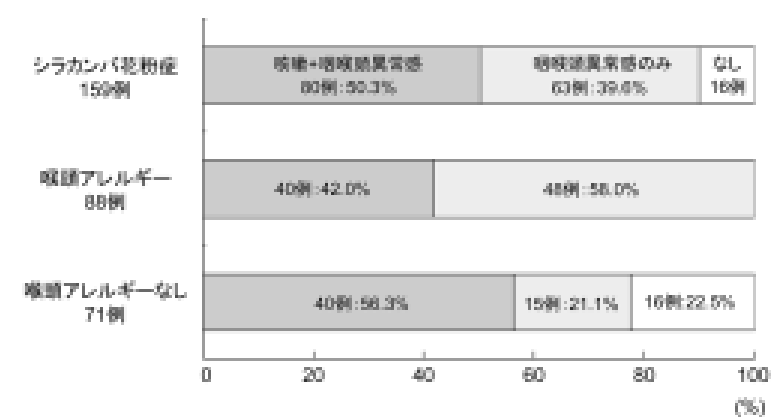

図 3 シラカンバ花粉症患者および喉頭アレルギー患者の咽喉頭 症状 
旭川市周辺に扔けるシラカンバ花粉の飛散時期は 4 月 下旬から 6 月上旬である。 シラカンバ花粉症患者に抢け る咳嗽や咽喉頭異常感の月別出現頻度について検討した。 回答は症状が認められる月を選択するものとした（複数回 答可)。図 4 に示したように，花粉飛散時期に一致して咳 嗽や咽喉頭異常感を訴える患者が増加していた。この傾向 は，喉頭アレルギーと喉頭アレルギーなしの両群に共通し ていた。

咳嗽については, シラカンバ花粉症患者全体で 80 例 (50.3\%), 喉頭アレルギー症例 88 例中 40 例 $(42.0 \%)$, 喉頭アレルギーなし 71 例中 40 例 $(56.3 \%)$ で認められた (図 3)。咳嗽の性状は喀痰を伴わない乾性咳嗽と喀痰を喀 出するための湿性咳嗽に分類され，喉頭アレルギーを含め たアトピー素因が関与する咳嗽は，乾性であることが多 い ${ }^{15)}$ とされている。今回の結果でも，咳嗽の性状は湿性 よりも乾性が多く, この傾向はシラカンバ花粉症全体, さ らに喉頭アレルギーおよび喉頭アレルギーなしの両群に共 通していた（図 5)。咳嗽発作の程度については 1 日に 10 回以下の比較的軽度である症例が約 $75 \%$ と高率であった (図 5)。

咽喉頭異常感は咳嗽に比べて頻度が高く，シラカンバ花

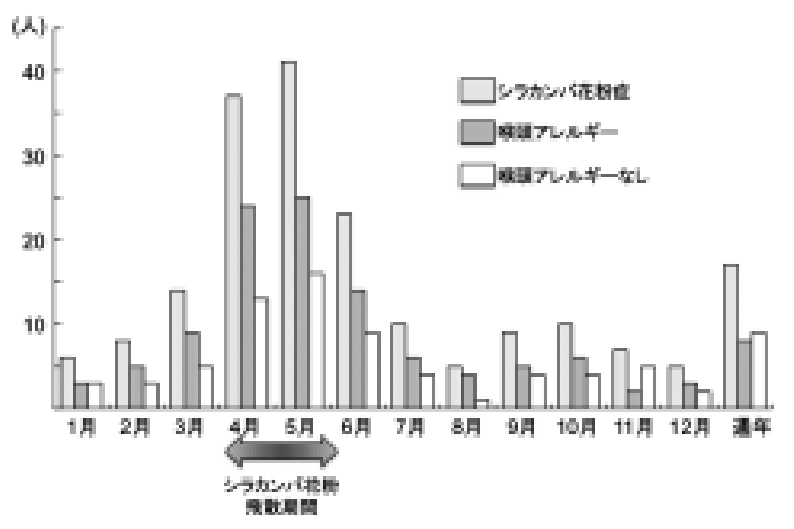

図 4 咽喉頭症状の季節変化
粉症全体では 143 例 (89.9\%), 喉頭アレルギー症例は全 例 (100\%)，喉頭アレルギーなしの 71 例中 40 例 (77.5\%) で認められた（図 3)，異常感の性状について検討するため に，アンケートの回答を大きく 8 つ感覚に分類して図 6 のようなレーダーチャートに示した，喉頭アレルギー症例 ではのどの乾燥感や掻痒感を訴える患者が多く，つまった 感じや痰の絡む感じを訴える患者は少ない傾向があった。 喉頭アレルギーなしの症例では喘鳴や痰の絡む感じを訴え る頻度が他に比べて高い傾向が認められた。これは喘鳴や 後鼻漏があることで，喉頭アレルギーから除外された症例 が含まれているためと考えられた。

今回対象とした 159 例中の 88 例 $(55.3 \%) に O A S の$ 合 併が認められた。原因食物としては頻度の高いものからリ ンゴ $(27.8 \%)$, サクランボ $(16.5 \%)$, モモ $(11.4 \%)$ と なっていた。喉頭アレルギーと診断される症例で高率に OASの合併が認められるかどうか検討をおこなったが, 喉頭アレルギー 88 例でOASを合併していた症例は 48 例 (54.5\%) であり，喉頭アレルギーなしと診断された 71 例 では 40 例 $(56.4 \%)$ であった（図 7 ）。今回用いた新しい 診断基準案による診断では, 喉頭アレルギー症例にOAS 合併頻度が高いという傾向は認められなかった。

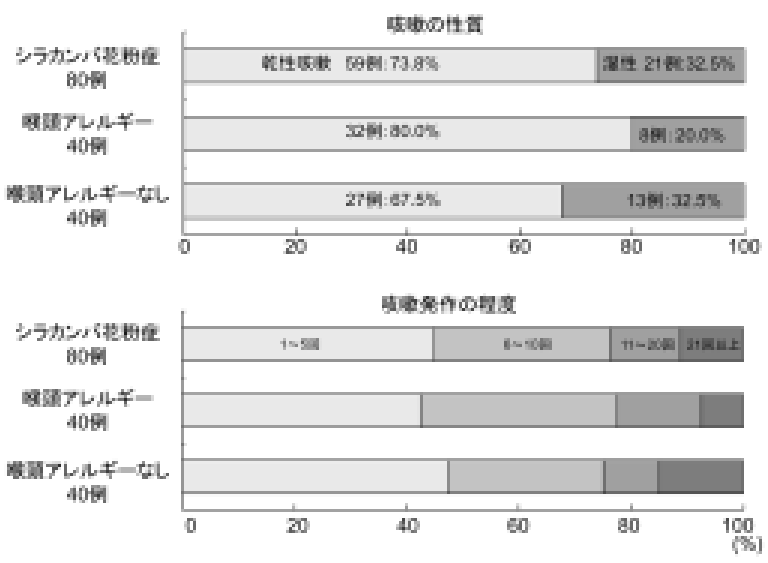

図 5 咳嗽の性質と程度

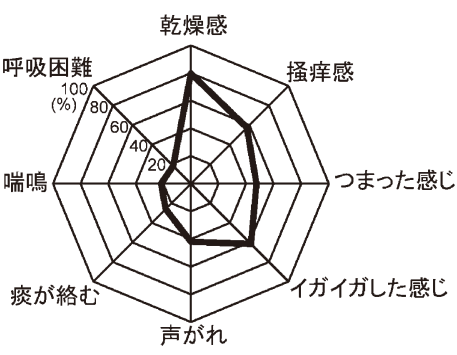

シラカンバ花粉症 159例
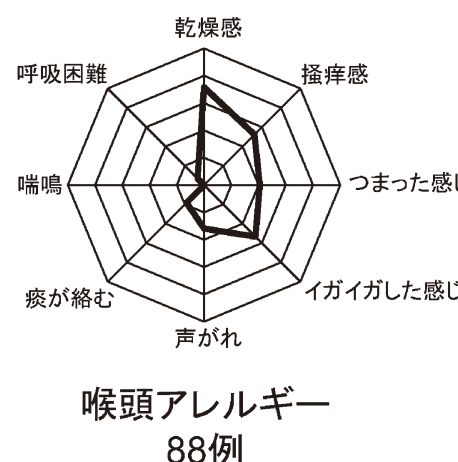
88 例

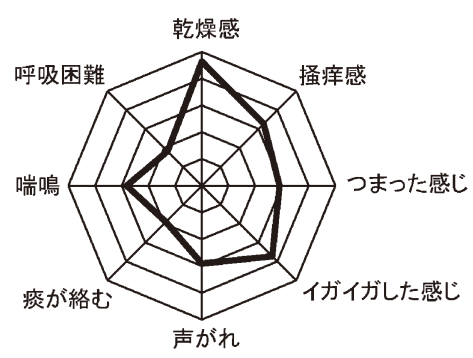

喉頭アレルギーなし 71例

図 6 咽喉頭異常感の性状 


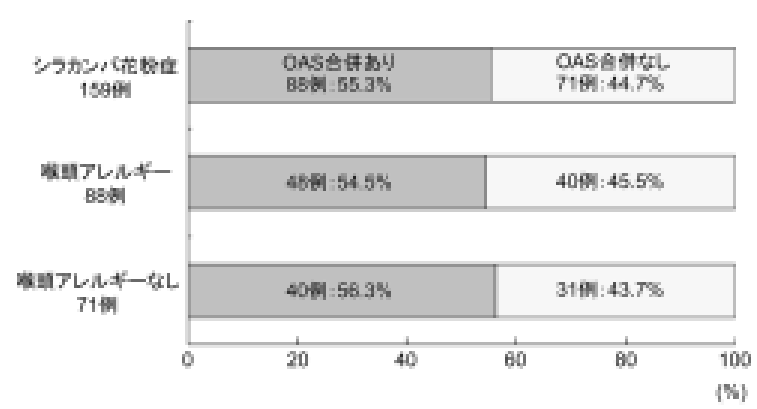

図 7 口腔アレルギー症候群の合併率

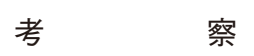

花粉症患者が原因花粉の飛散時期に一致して咽喉頭異常 感や咳嗽などの咽喉頭症状を訴えることは以前からよく知 られている ${ }^{4)}$. また, 基礎的研究からは喉頭粘膜を反応の 場とするI 型アレルギー反応が惹起されることも確認され ている ${ }^{6,16)}$. 従って, 花粉症患者における花粉飛散時期の 咽喉頭症状の出現には, 喉頭への花粉の暴露によるアレル ギー反応が関与していると推察されている ${ }^{17)}$ 。これまで に，スギ花粉症おける喉頭アレルギーに関する報告は散見 されるが ${ }^{17 \sim 20)}$ ，北海道を代表する樹木花粉症であるシラ カンバ花粉症における喉頭アレルギーに関する報告は少な い ${ }^{13,21)}$. 喉頭アレルギーについては，1995 年に喉頭アレ ルギー研究会世話人会から診断基準が提唱された。その後 2000 年と 2005 年に 2 度新しい基準の提唱があった。本研 究ではシラカンバ花粉症患者において, 最も新しい診断基 準案に基づいた喉頭アレルギーの診断をおこない，その合 併率や咽喉頭症状について検討した。

2005 年に見直しがおこなわれた新しい診断基準案に基 づいて, シラカンバ花粉症患者に打りる喉頭アレルギーの 診断をおこなったところ，159 例中 88 例 $(55.3 \%)$ が季節 性喉頭アレルギーのきびしい診断基準案に合致していた。 以前に我々は，1995年に提唱された診断基準に基づくシ ラカンバ花粉症患者における喉頭アレルギー確実例の頻度 が 119 例中の 58 例 $(48.7 \%$ ) であったことを報告してい る ${ }^{21)}$ 。これまでの 2 度にわたる診断基準の見直しは咳喘 息，アトピー咳嗽，アレルギー性気管支炎，非喘息性好酸 球性気管支炎といったアトピー素因の関与する慢性咳嗽を 引き起こす疾患と喉頭アレルギーとの鑑別を目的としたも のである ${ }^{14)}$ 。また, 新しい診断基準案では喉頭アレルギー を通年性と季節性に明確に分けている。診断基準がより厳 密化されたことによって，シラカンバ花粉症において季節 性喉頭アレルギーと診断される患者の頻度は減少すると予 想されたが, 本研究の結果では以前と同等の頻度であるこ とが確認された。

喉頭アレルギーの 2 大症状は咽喉頭異常感と執拗な咳嗽 である。咽喉頭異常感についてはシラカンバ花粉症患者
159 例中 143 例 $(89.9 \%)$ と非常に高頻度に認められ，喉 頭アレルギーではないと診断された患者でも 71 名中 55 例 (77.4\%) に咽喉頭異常感が認められた。 スギ花粉症にお ける咽喉頭異常感の合併は $64 \sim 78.2 \%{ }^{6,8,17,18)}$ といわれて おり，シラカンバ花粉症と同様に高頻度であった。花粉症 患者が咽喉頭異常感を訴えやすい背景としては, 原因花粉 の喉頭粘膜への直接暴露（喉頭アレルギー）の他，花粉飛 散時期の鼻症状の悪化による後鼻漏の増多や，鼻閉による 口呼吸に起因した咽頭粘膜の乾燥などが想定される。今回 の検討では，シラカンバ花粉が多く飛散する 4 月から 6 月 にかけて咽喉頭異常感が高頻度に認められ, その性状は乾 燥感と掻痒感の頻度が高かった。これもスギ花粉症の咽喉 頭異常感と同様の傾向であった ${ }^{6)}$.

今回の我々の検討ではシラカンバ花粉症患者の $50.3 \%$ に咳嗽の訴えが認められ，73.8\%が乾性咳嗽であった。 ス ギ花粉症の場合，約 $64 \%$ の患者に咳嗽が認められ， $75 \%$ が乾性咳嗽であったと報告されている。また発作頻度は比 較的軽度であることも報告されている ${ }^{15)}$. 以上の特徵は シラカンバ花粉症においても同様であった。 また, 喉頭ア レルギーと診断されなかった患者では乾性咳嗽の割合が $67.5 \%$ であのに対して，喉頭アレルギーと診断された患 者の乾性咳嗽の割合は $80 \%$ と高い傾向が認められた。喉 頭アレルギーの診断項目として乾性咳嗽であることが明記 されており，喉頭がI型アレルギー反応の場となっている ことを示唆するものであると考えられた。

今回のきびしい基準では，胃食道逆流症や後鼻漏があれ ば喉頭アレルギーとは診断されないことになっている。こ れは, 咽喉頭異常感や咳嗽が胃酸の逆流や鼻症状の悪化に よるものではなく喉頭粘膜でのI 型アレルギー反応による ものである可能性を高めるための項目であると理解され る、今回のアンケートの結果で吃逆, 胸焼け, 吞酸を訴え ていた症例は 25 例 $(15.7 \%)$, 明確な後鼻漏を訴えていた 症例が 8 例 (5.0\%) であり, 合計 33 例 (20.8\%) が喉頭ア レルギーから除外された。しかし，この診断基準からはず れた患者であっても, 訴える咽喉頭異常感に季節性の症状 の変動が認められる場合もあり, 症状のみからの喉頭アレ ルギー患者との明確な鑑別は困難であると思われた。日常 診療においても, 難治性の咽喉頭異常感に対して抗アレル ギー剤とプロトンポンプインヒビターを併用することで症 状が軽快することも少なからず経験される。より㛜密な診 断を目指すために胃食道逆流症や後鼻漏を除外項目として いるが, 喉頭アレルギーに胃食道逆流や後鼻漏症候群を合 併している症例も存在している可能性が推察された。

シラカンバ花粉症患者にはOASの合併がよく知られて いる ${ }^{10,11)} .1995$ 年の喉頭アレルギー診断基準では, 執拗 な咳嗽と咽喉頭異常感があり，それらの症状の発現が食 餌, 季節と関係する場合は喉頭アレルギー確実例に分類さ れていた。この診断基準を用いると，OASを合併してい るシラカンバ花粉症患者では， $72 \%$ が喉頭アレルギー確実 
例となりさらに疑い例までを含めると $90 \%$ の患者が喉頭 アレルギーと診断されていた ${ }^{13)}$ 。この結果から，われわ れはこの診断基準が OAS と喉頭アレルギーとの鑑別につ いては不向きであると考えていた，今回，2005 年の新し い診断基準案に基づいて検討をおこなったところ，OAS を合併しているシラカンバ花粉症患者は 159 例中 88 例 (55.3\%)，喉頭アレルギーと診断された患者でOASを合 併している患者数は 88 例中 48 例 $(54.5 \%)$, 喉頭アレル ギーではない患者でOASを合併している患者数は 71 例中 40 例（56.3\%）となっており, 新しい診断基準案ではOAS の有無は喉頭アレルギーの診断にほとんど影響していない と考えられた。

$$
\text { ま と め }
$$

新しい季節性喉頭アレルギーの診断基準案（2005 年）に 基づいて, シラカンバ花粉症における喉頭アレルギーの合 併率や咽喉頭症状について検討した。

診療録とアンケート調査の結果からシラカンバ花粉症患 者 159 例中 88 例 $(55.3 \%)$ が季節性喉頭アレルギーと診 断された。

季節性喉頭アレルギー症例では花粉飛散時期に一致して 咽喉頭症状が出現し, 執拗な咳嗽は 88 例中 40 例 ( $42.0 \%)$ に, 咽喉頭異常感は 88 例全例 (100\%)に認められた。咳 嗽は乾性咳嗽の頻度が高く, 咽喉頭異常感はのどの乾燥感 や掻痒感を訴える患者が多かった。

季節性喉頭アレルギー 88 例で口腔アレルギー症候群を 合併していた症例は 48 例 $(54.5 \%)$ であった。 その一方 で喉頭アレルギーなしと診断された 71 例においても 40 例 (56.4\%) で口腔アレルギー症候群の合併があり, 今回用 いた新しい診断基準案では，喉頭アレルギー症例では特に 口腔アレルギー症候群の合併頻度が高くなるという傾向は 認められなかった。

本論文の要旨は, 第 21 回日本喉頭科学会総会・学術講 演会 (前橋) で発表した。

\section{参 考 文 献}

1) Pang L. Q. : Allergy of the larynx, trachea, and bronchial tree. Otolaryngol Clin North Am 7 : 719 - 734, 1974.

2) Williams R. I. : Allergic laryngitis. Ann Otol Rhinol Laryngol $81: 558-565,1972$.

3) Brodnitz F. S. : Allergy of the larynx. Otolaryngol Clin North Am 4 : 579-582, 1971.

4）堀口申作, 斉藤洋三：栃木県日光地方におけるスギ花 粉症 Japanese Cedar Pollinosisの発見. アレルギー
$13: 16-18,1964$

5）今野昭義, 吉田 耕, 神田 敬：喉頭アレルギーの病 態と治療。耳喉・頭頸外科 $23: 205-212,1992$.

6）岩田重信, 内藤健晴, 井畑克朗ほか：喉頭アレルギー の基礎と臨床.耳鼻と臨床 41 補 $2: 839-851,1995$.

7）山口智子, 寺田哲也, 桜井幹士ほか：アレルギー性鼻 炎患者の喉頭症状について。耳鼻免疫アレルギー 18:194-195, 2000.

8）石田春彦：咽喉頭異常感の現況と対策 咽喉頭異常感 と喉頭アレルギー。日気食会報 52:96-100，2001。

9）間口四郎, 高木摂夫, 吉田美果ほか：シラカンバ花粉 症札幌に扮ける現況とハンノキ属との共通抗原性に ついて。 日耳鼻 $96: 1-9,1993$.

10）東松环郎, 松井玲子, 川堀眞一：シラカンバ花粉症と oral allergy syndrome. 耳鼻臨床 91:811-815, 1998.

11）熊井惠美：当院に打けるシラカンバ花粉症と口腔アレ ルギー症候群， 口腔咽頭 $13: 179-188,2001$.

12) Ortolani C, Ispano $M$, Pastorello $E$ et al : The oral allergy syndrome. Ann Allergy 61:47-52, 1988.

13）野中 聡, 片田彰博, 国部勇ほか：シラカンバ花粉症 患者に扔ける喉頭アレルギー 特にoral allergy syndromeとの関係について。喉頭 13:47-50, 2001.

14）内藤健晴：喉頭アレルギー。慢性咳嗽の診断と治療に 関する治療指針（2005 年版），(藤村政樹）。16-21， 前田書店，金沢市，2006.

15）石田春彦：【せきその診断と治療】喉頭アレル ギー. MB ENT 59:39-45, 2006.

16）岩江信法, 石田春彦, 天津睦郎：モルモット喉頭にお けるI型アレルギー。喉頭 7:1-6, 1995 。

17）前山忠嗣, 津田邦良：【咽喉頭異常感症の扱いをめぐっ て】咽喉頭異常感症とスギ花粉症. JOHNS 15： 231-234, 1999.

18）神田 敬: 気管, 食道周辺領域の粘膜免疫反応 喉頭 アレルギーとスギ花粉症. 日気食会報 $48: 91-93$, 1997.

19）内藤健晴，岩田重信、妹尾淑郎ほか：【スギ花粉症】ス ギ花粉症にみられる喉頭アレルギーとその対応.アレ ルギー科 $5: 162-166,1998$.

20）岩田重信 :【アレルギーと知覚過敏】喉頭アレルギー と乾性咳嗽。アレルギーの領域 5:300-307, 1998.

21）国部 勇, 野中 聡, 片田彰博ほか：シラカンバ花粉 症患者に抢ける咽喉頭症状。喉頭 $15 ： 28-34,2003$.

別刷請求先 $=078-8510$ 旭川市緑が丘東 2 条 $1 丁$ 目 1-1 旭川医科大学耳鼻咽喉科・頭頸部外科 片田彰博 